\title{
1. Promoting stabilizing and sustainable sub-national fiscal policies in the Euro area
}

\section{Teresa Ter-Minassian}

\section{INTRODUCTION}

The Euro area (henceforth EA) has been buffeted by major shocks in the last five years or so, first the global financial crisis and subsequently its own crisis, which affected most acutely the so-called 'periphery' (Cyprus, Greece, Ireland, Italy, Portugal and Spain), but also impacted adversely, because of its economic and financial integration, the rest of the area. There are, as of mid-2014, incipient signs of recovery of confidence and demand in most of the EA, but growth in output remains subdued, and too low to make a significant dent in the area's historically high unemployment rates. The stresses associated with needed adjustments continue to have political reverberations, especially in Greece.

The public finances of the EA member countries have been sharply impacted by the two crises, through the operation of the automatic stabilizers, discretionary stimulus packages in 2008-09, and in some countries the realization of contingent liabilities, particularly from rescue operations for domestic banks. The average overall general government (GG) deficit in the EA jumped from under 1 percent of GDP in 2007 to over 6 percent of GDP in 2009-10, and remains slightly above 3 percent of GDP, despite substantial fiscal consolidation efforts in a number of the area's countries (Figure 1.1). ${ }^{1}$ All but three of the EA countries still recorded structural fiscal deficits in 2013. The average gross public debt rose by nearly 30 percentage points of GDP between 2007 and 2013, to over 95 percent of GDP (Figure 1.2).

Against this background, it is clear that significant further fiscal adjustment efforts are going to be needed by most EA countries in the years ahead, although views can legitimately differ on the appropriate pace of such adjustment. ${ }^{2}$ Given the substantial, and in some countries still growing, role of the sub-national (state/regional and local) governments 


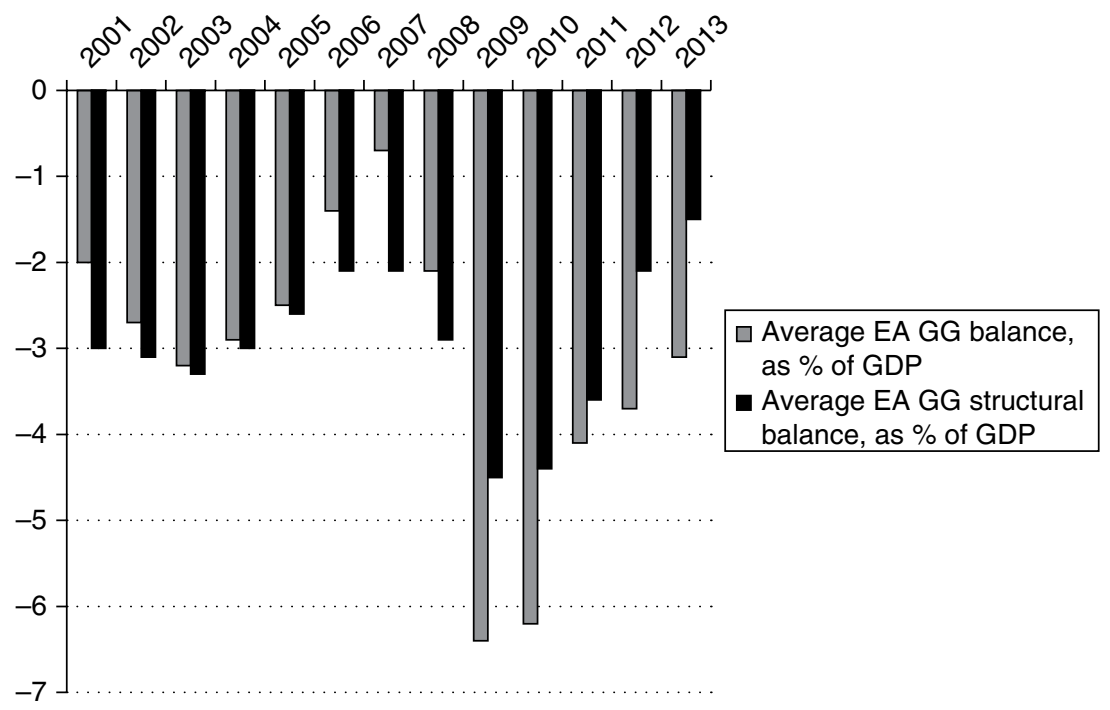

Source: IMF database.

Figure 1.1 Average actual and structural fiscal balances in the EA

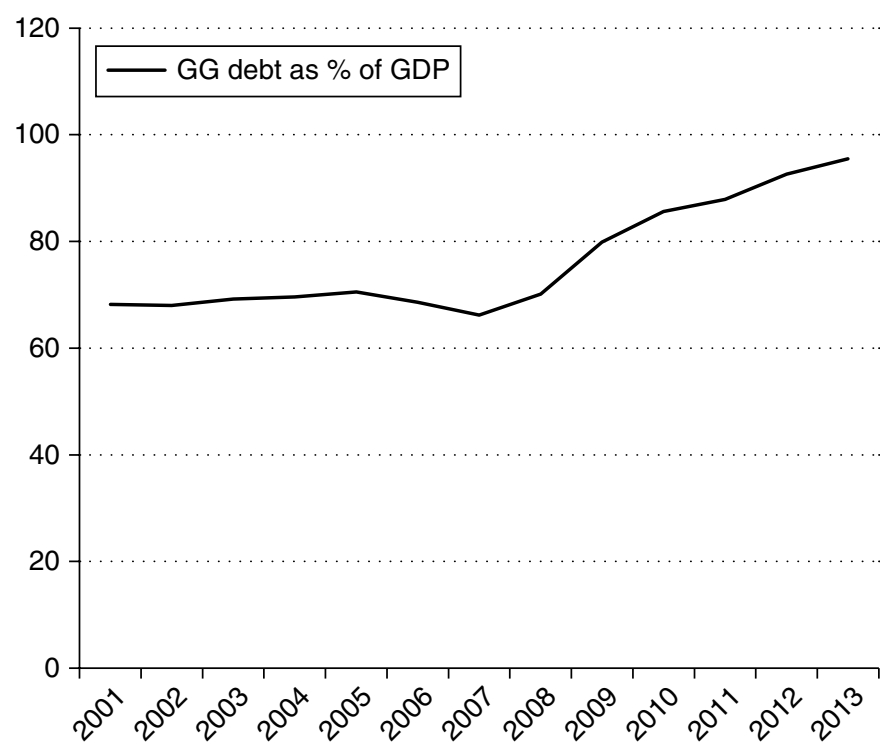

Source: IMF database.

Figure 1.2 Average gross public debt in the EA 
(SNGs) in the delivery of essential public goods and services (as well as investments?) in the EA, SNGs will need to contribute to such adjustments, and in as efficient and equitable a manner as possible.

The impact of the global and Euro crises on the public finances of the EA, and the policy responses to them at both the national and the European Union (EU) levels, have been amply analyzed in the literature in recent years. There has been more limited focus on the effects of the crises on the area's SNGs, and on their policy responses. ${ }^{3}$ This chapter analyzes developments in the EA's sub-national finances during the crisis period 2008-12, drawing lessons from this analysis for future sub-national fiscal policies and management.

Section 2 provides a brief review of the impact of the crises on subnational finances in the EA as a whole and, in particular, in the 'periphery' countries. Some of these experiences are analyzed in much greater detail in the case studies included in the book. Section 3 discusses the main types of institutional arrangements used by EA countries in recent years to promote sub-national fiscal discipline and sustainability, as well as broad consistency with the nation-wide requirements of the evolving EU fiscal framework. The section also reviews the limited empirical evidence available to date on the effectiveness of these arrangements. Section 4 looks at the challenges that the recent reforms of the EU fiscal framework (in particular under the so-called Six-Pack and Fiscal Compact) pose for intergovernmental fiscal relations in the EA. Section 5 presents some conclusions.

\section{A BRIEF REVIEW OF THE IMPACT OF THE RECENT CRISES ON THE SUB-NATIONAL FINANCES IN THE EA}

The EA's member countries present a wide array of intergovernmental fiscal arrangements, differing in the degree of revenue and expenditure decentralization, ${ }^{4}$ statutory and de facto autonomy of their SNGs, and systems of borrowing controls. Four of the countries (Austria, Belgium, Germany and Spain) are federations, the other fourteen are unitary states. However, there is no clear correlation between the federal or unitary structure and the degree of decentralization. Therefore, area-wide averages mask significant variance across the EA, and may not be representative of developments in individual countries. With this caveat, Figures 1.3-1.6 present a broad picture of developments in the EA's sub-national finances in the run-up to and the aftermath of the global financial and the Euro crises. 


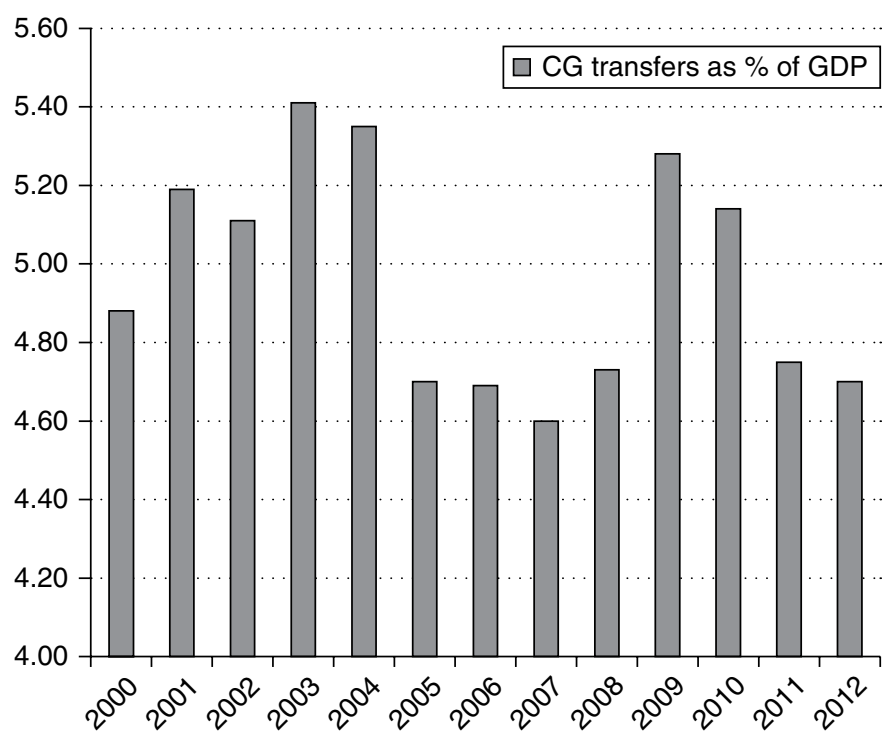

Source: OECD Fiscal Federalism Network database.

Figure 1.3 Average transfers from the CG to SNGs in the EA

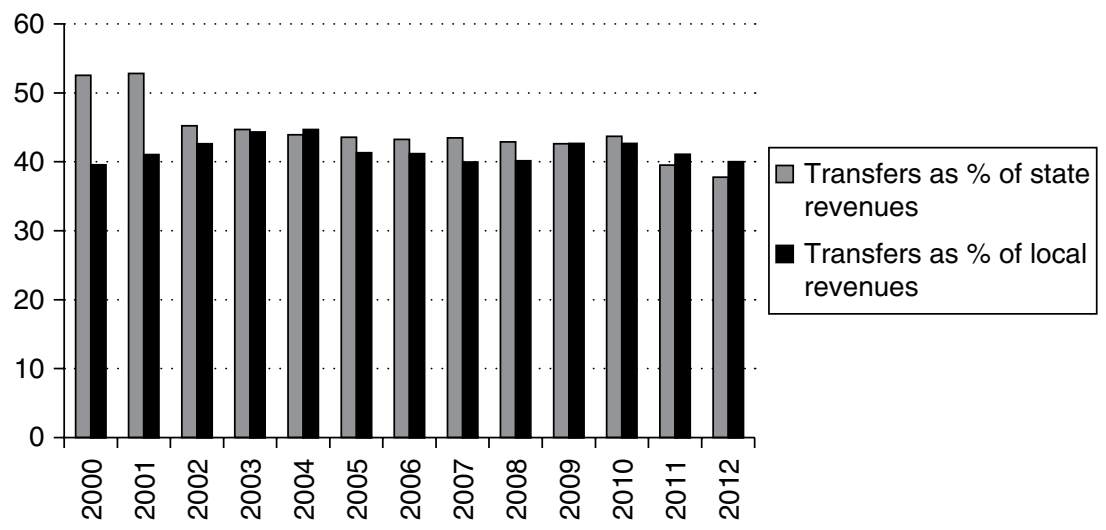

Source: OECD Fiscal Federalism Network database.

Figure 1.4 Average composition of sub-national revenues in the $E A$ 


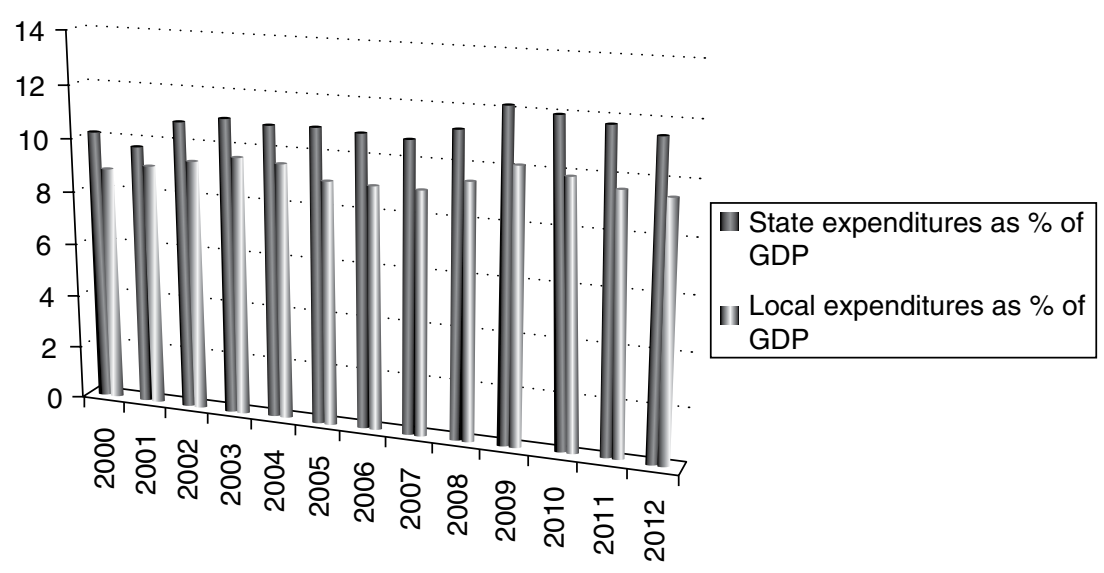

Source: OECD Fiscal Federalism Network database.

Figure 1.5 Average state and local expenditures in the EA

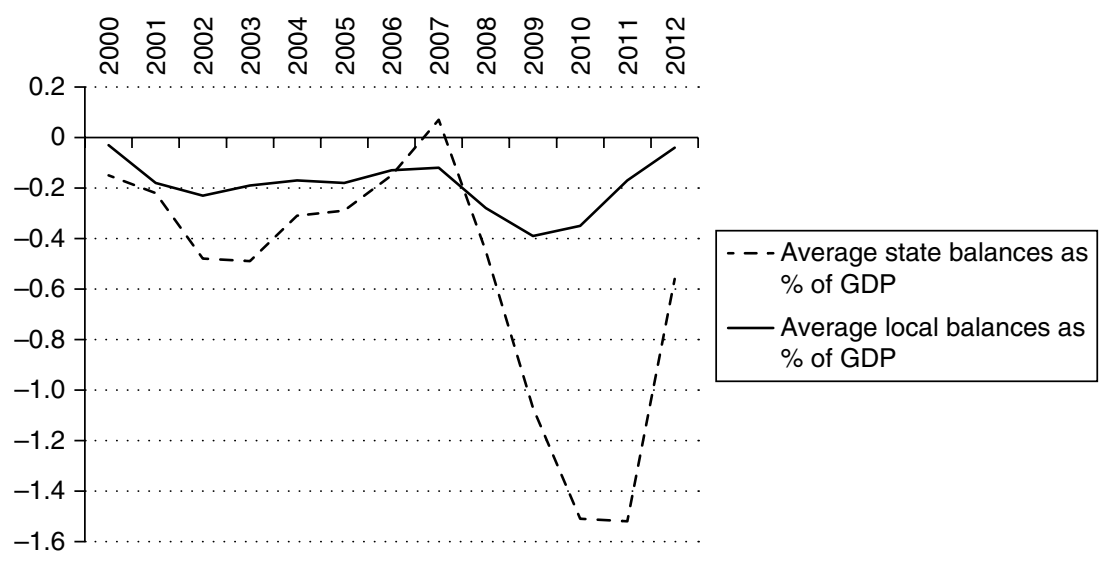

Source: OECD Fiscal Federalism Network database.

Figure 1.6 Average state and local balances in the EA

As is well known, the initial reaction of most EA central governments (CGs) to the global financial crisis in 2008 was not only to accommodate the effect of the automatic fiscal stabilizers on revenues and cyclically sensitive expenditures, but also to adopt (more or less significant) stimulus packages 
to support the rapidly falling domestic demand. ${ }^{5}$ These packages included a variety of tax cuts, increases in transfers to households and firms, and cuts in public investments. In many of the countries, national governments channeled a substantial share of the increased spending through their SNGs, boosting transfers to the latter, to compensate for falling sub-national own or shared revenues, support social assistance programs, and carry out additional public investments (Figure 1.3). As a result, both the share of intergovernmental transfers in total sub-national revenues and the share of sub-national spending in GDP increased appreciably during 2008-09 (Figures 1.4 and 1.5).

Moreover, a number of the EA countries suspended or eased existing legal or administrative limits on sub-national borrowing, allowing increases in subnational deficits, especially marked at the state level, in 2008-09 (Figure 1.6). As a result, sub-national debt, which had been broadly stable as percent of GDP during the first half of the 2000s, began a steady upward trend (Figure 1.7). On the whole, the fiscal response of SNGs to the global crisis was clearly counter-cyclical during 2008-09 in most of the EA countries.

Concern with mounting national and sub-national debts, as well as signs of a fledgling recovery from the global crisis, led many countries in the EA to embark on a fiscal consolidation path in 2011-12, which included cutbacks in central government (CG) transfers to SNGs (Figure 1.3). Sub-national spending was, however, cut back even more, leading to some improvement in the average state and local balances in the EA. Subnational debt continued to rise, albeit at a moderating pace. As output gaps

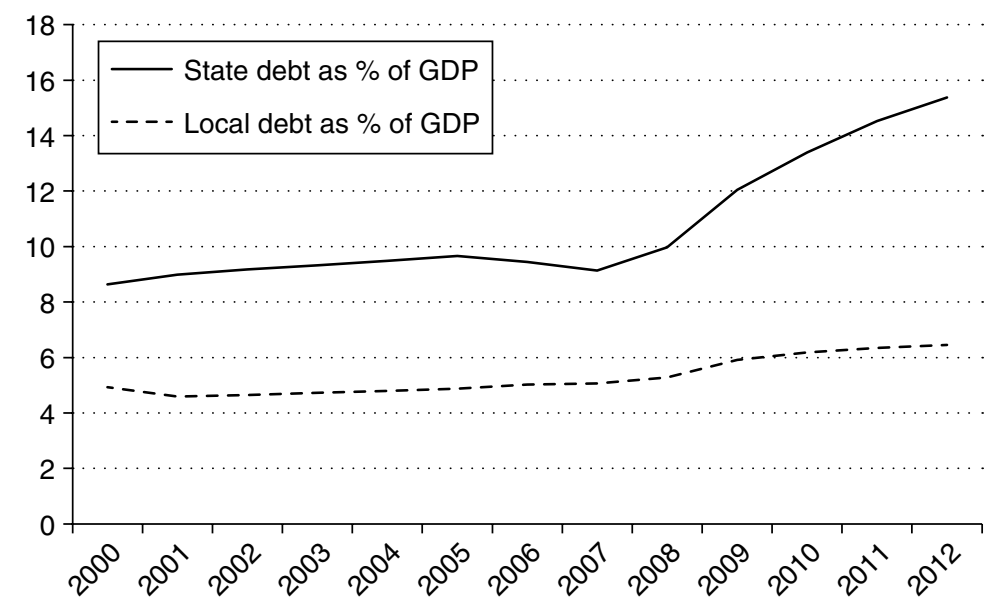

Source: OECD Fiscal Federalism Network database.

Figure 1.7 Average state and local debt in the EA 


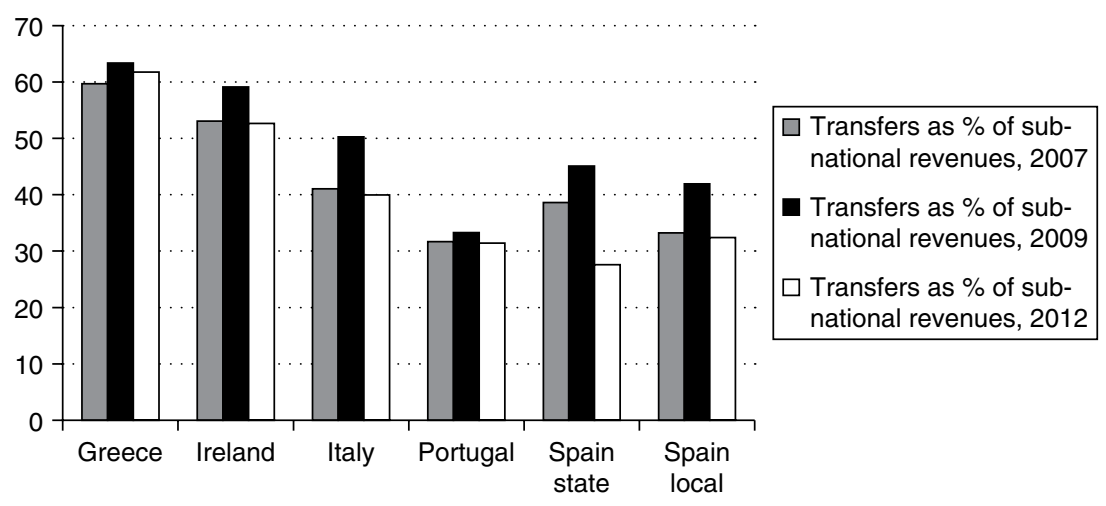

Source: OECD Fiscal Federalism Network database.

Figure 1.8 Impact of the crises on intergovernmental transfers in the EA 'periphery'

remained significantly negative in most of the EA during 2010-12, the withdrawal of fiscal stimulus at the sub-national, as well as the national, level implied a shift to a pro-cyclical fiscal stance.

The average EA trends were magnified in the 'periphery' countries, where the initial fiscal easing at the outset of the global financial crisis was more than rolled back, as financing constraints associated with markets' loss of confidence forced abrupt and strong fiscal adjustment at both the national and the sub-national levels. CG transfers to SNGs were reduced (more or less sharply) in all the 'periphery' countries between 2009 and 2012 (Figure 1.8). Sub-national spending was further constrained by financing difficulties (Figure 1.9), leading to significant improvements in subnational fiscal balances in most of the periphery countries (Figure 1.10). Sub-national debt broadly stabilized as percent of GDP in Greece, Ireland and Italy, but continued to rise in Portugal and Spain (Figure 1.11), partly reflecting the recognition of previously accumulated liabilities.

The composition of the sub-national fiscal consolidation has varied across the 'periphery' countries, with some (e.g., Italy) relying significantly on tax increases, and others more on expenditure cuts. In all countries, however, public investment bore the brunt of the adjustment. Moreover, in some of the countries, the crisis altered the political balance of powers among the different levels of government, providing the respective CGs an opportunity to tighten financial controls over their SNGs. A detailed account of developments in the sub-national finances of several 'periphery' countries is provided in the respective case studies. 


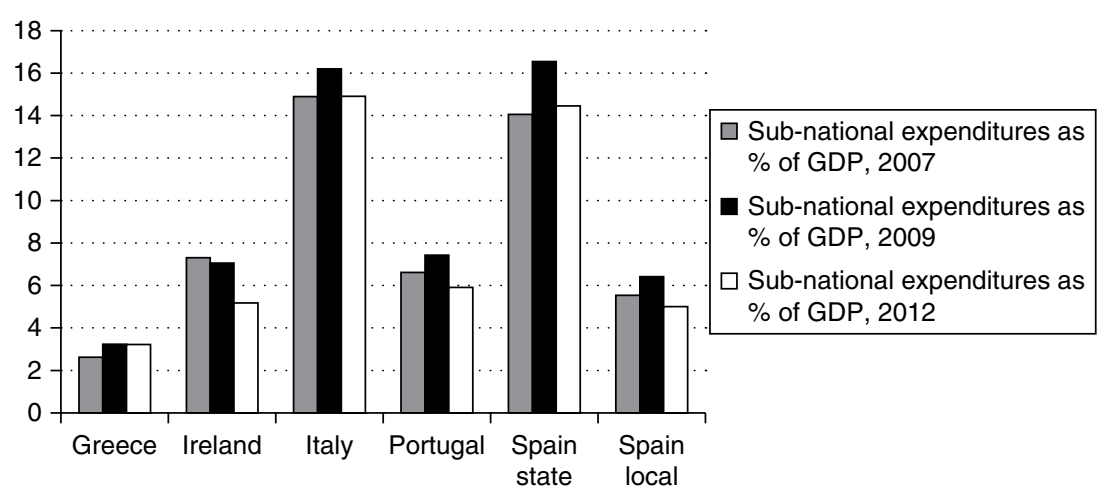

Source: OECD Fiscal Federalism Network database.

Figure 1.9 Impact of the crises on sub-national spending in the EA 'periphery'

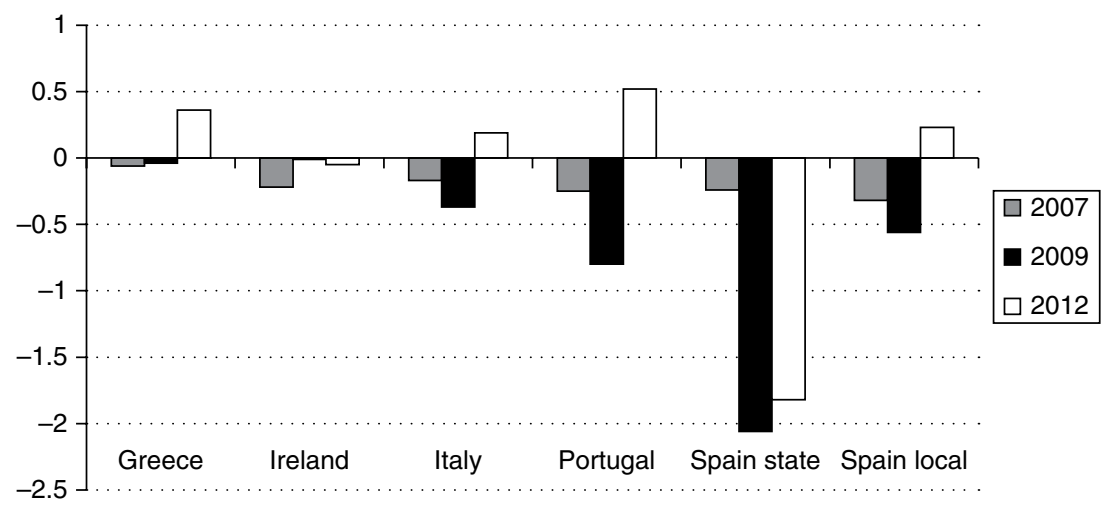

Source: OECD Fiscal Federalism Network database.

Figure 1.10 Sub-national budget balances in the EA 'periphery'

\section{ARRANGEMENTS TO PROMOTE SUB-NATIONAL FISCAL DISCIPLINE IN THE EA}

\subsection{Overview}

CGs around the world are concerned with ensuring sub-national fiscal responsibility and longer-term debt sustainability, and use a range of 


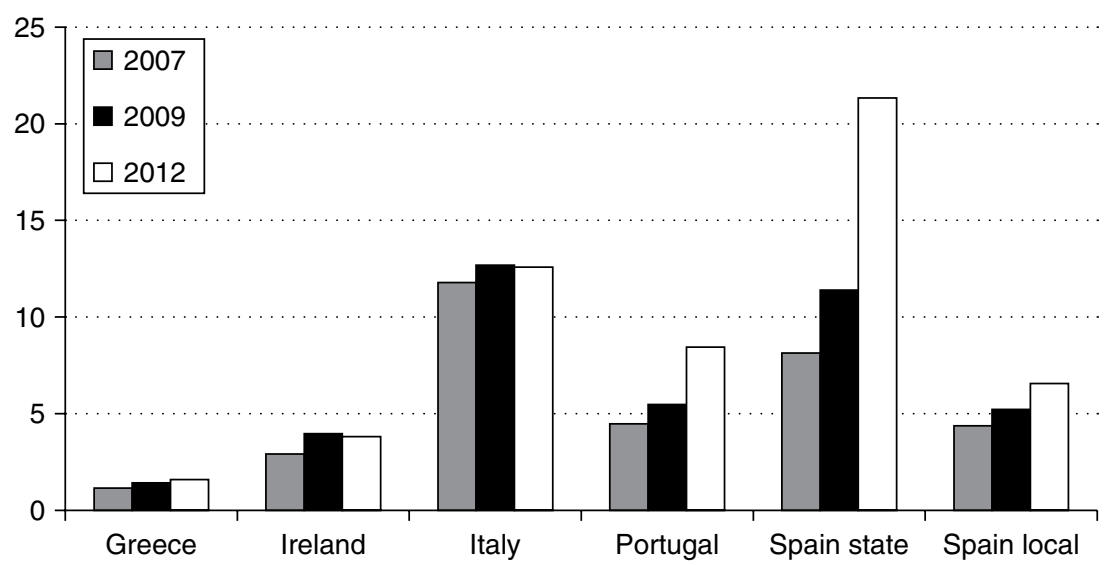

Source: OECD Fiscal Federalism Network database.

Figure 1.11 Sub-national debt in the EA 'periphery'

different types of borrowing controls to promote these objectives, with varying degrees of effectiveness. Some are also concerned with minimizing pro-cyclicality and avoiding substantial fluctuations in the delivery of essential public services of sub-national responsibility, and pursue these objectives through a variety of tools, such as counter-cyclical intergovernmental transfers, requiring SNGs to create rainy day funds, etc.

For EA countries, there is an additional challenge: ensuring that fiscal developments at the sub-national levels are consistent with the fiscal balance and public debt requirements of the EU, which refer to the general government, but hold the CG responsible for compliance. This section presents an overview ${ }^{6}$ of the arrangements that EA countries have used in recent years to promote sub-national fiscal discipline (Table 1.1), and briefly discusses the limited available empirical evidence on their effectiveness.

The following section discusses the increasing challenges in this respect that recent reforms in the EU fiscal framework are posing for EA members.

Table 1.1 suggests that arrangements to promote sub-national fiscal discipline and debt sustainability have varied significantly across the EA in recent decades. Of the four main types of such arrangements, standing fiscal rules have been by far the most common. Although most countries have various institutional mechanisms for intergovernmental coordination, only a few (mainly federal or quasi-federal) have relied on (more or less) negotiated arrangements (the so-called Internal Stability Pacts) as the main instrument to secure sub-national fiscal discipline. Primary reliance 


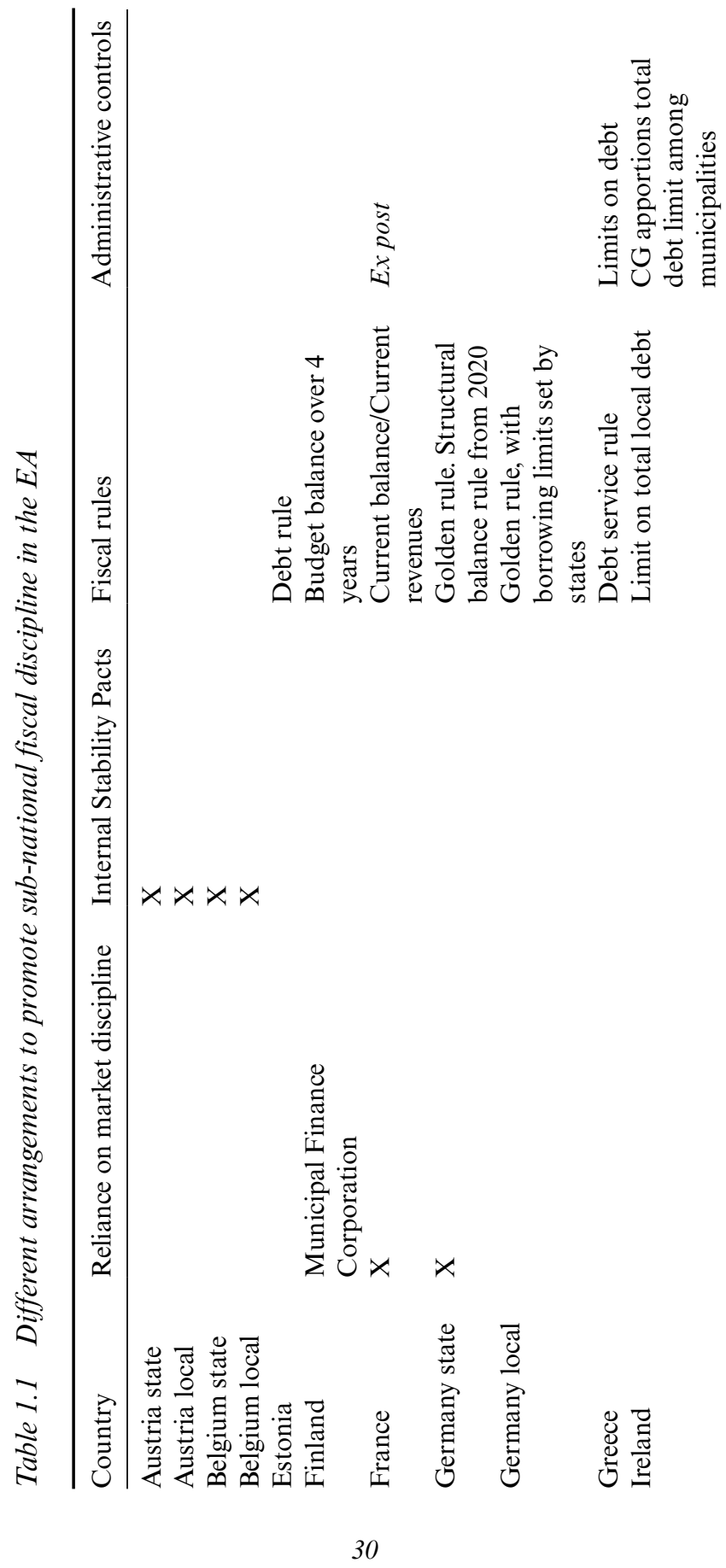




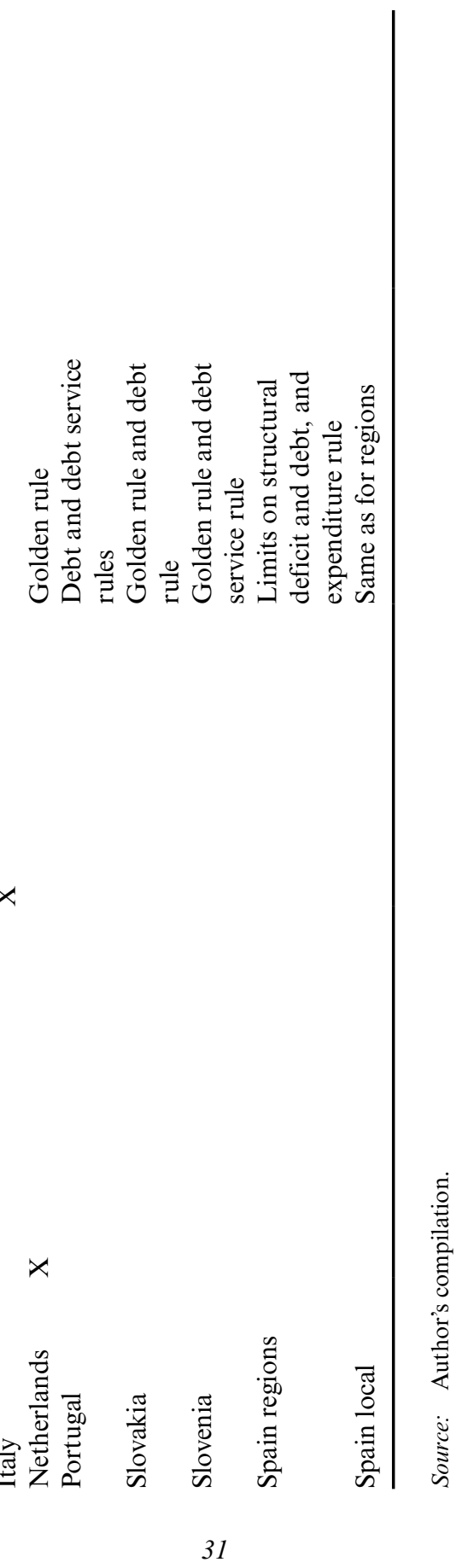


on market discipline or on administrative ex ante $\mathrm{CG}$ controls on subnational borrowing has been rare in the EA.

\subsection{Fiscal Rules}

Sub-national fiscal rules used in EA countries have typically focused on ensuring debt sustainability, while preserving some room for borrowing to finance public investments. Accordingly, the most common combination has been that of a golden rule (requiring that SNGs' current budgets be at least balanced) with limits on sub-national debt stocks or debt service, relative to the SNGs' current revenues. Some countries have used rules on the composition of sub-national borrowing, e.g., by prohibiting their SNGs from issuing bonds, but not from borrowing from banks.

Few countries have utilized standing rules targeting the overall (as opposed to the current) balance, although targets for the latter have been frequently included in the Internal Stability Pacts (see next sub-section). None has yet targeted sub-national structural or cyclically adjusted balances (although Finland has used a rule requiring balance over a fouryear period). A growing, but still small, number of countries have used expenditure-based rules.

In most countries, the debt or balance limits have been applied to individual SNGs. In Ireland, the debt limit is instead specified for the local government level as a whole, and the CG is empowered to distribute it among the individual localities.

The coverage of the rules has been typically restricted to public administration, excluding enterprises owned or controlled by individual SNGs, thus creating a potential loophole that has been utilized by many SNGs to circumvent the limits. Another vehicle to escape the constraints imposed by the rules has been the recourse by SNGs to PPPs, since contingent or actual future liabilities incurred under such arrangements are typically not covered by the debt limits. Significant examples in this respect have been the region of Madeira in Portugal (see Ahmad, Chapter 2 in this volume) and some of the regional governments in Spain. Some countries have sought to limit sub-national exposure to contingent liabilities by setting ceilings on the guarantees provided by their SNGs.

The monitoring of compliance with sub-national fiscal rules remains fraught with weaknesses, despite recent improvements in some of the countries, especially those under adjustment programs supported by the EU and the IMF. The main weaknesses in monitoring arrangements stem from the fact that controls typically focus on end-of-year accounts, which are available only with significant lags; and that sub-national accounts are often cash-based, and therefore do not allow a monitoring of arrears. Also, 
responsibility for the monitoring has frequently been shared among different agencies (e.g., the Ministries of Finance and of the Interior, and Audit Institutions), leading to duplication of tasks and reporting requirements, and ultimately to a dilution of accountabilities.

Experiences have varied regarding the rules' enforcement mechanisms. Legal provisions have included various types of financial sanctions for non-compliance, and the possibility of administrative interventions by upper levels of government (CG or state) in local administrations in serious financial distress. ${ }^{7}$ Some of the rules have also included provisions requiring non-complying SNGs to pursue a pre-specified correction path for their fiscal aggregates. There is, however, little evidence of actual application of such enforcement mechanisms so far.

In view of the above-mentioned weaknesses of monitoring and enforcement of sub-national fiscal rules, it is not surprising that the empirical evidence available to date points to a limited effectiveness of the rules in influencing sub-national fiscal outcomes. An IMF study (Escolano et al., 2012) found little or no evidence of effectiveness of fiscal rules on SNGs' fiscal performance in EU countries. Similar results were found by Blöchliger (2013) for OECD countries, based on simple correlation analysis. A 2012 analysis by the EC found limited effectiveness of sub-national rules targeting the budget balance, but a more significant one for rules targeting the debt. These rather disappointing results probably also reflect the fact that the studies did not control for other features of intergovernmental fiscal arrangements that affect the degree of 'softness' of the sub-national budget constraint (e.g., the degree of revenue autonomy of the SNGs, and the degree of discretionality of $\mathrm{CG}$ transfers to $\mathrm{SNGs}^{8}$ ).

\subsection{The Internal Stability Pacts}

Some of the EA countries have relied during the past decades on agreements between the CG and the SNGs regarding fiscal balances and debt (the so-called Internal Stability Pacts), rather than on standing fiscal rules. The main examples of such pacts can be found in federal countries (Austria, Belgium during 1992-2001), Spain ${ }^{9}$ and Italy.

The pacts have varied across countries in a number of dimensions, such as their duration; the nature, coverage, and level of their targets; the role played by the CG in their negotiations; and their monitoring and enforcement mechanisms. Such differences reflect the significant diversity of intergovernmental fiscal systems in the four countries, as well as the respective political power balances among government levels. The pacts have evolved over time, as steps have been taken to strengthen their effectiveness, mainly in response to the Euro crisis and to changes in the EU fiscal framework. 
Austria has had a series of Internal Stability Pacts, stipulating targets for sub-national fiscal balances, since 1996. The compliance record, initially strong, weakened after 2002, partly reflecting lack of enforcement, and was marred by sub-national resort to various accounting stratagems, such as reclassification of public entities. Deviations from the Pact's targets were especially pronounced during the crisis years, leading to a downward revision of the targets in 2011.

The 2012 Pact (which covers a transition period to the full implementation of the Fiscal Compact in 2017) sets nominal budget targets for all levels of government until 2016. From 2017 on, the CG will be required to limit its structural budget deficit to 0.35 percent of GDP, and the states theirs to 0.08 percent of their respective GDPs. Local governments' deficits should not exceed in aggregate 0.02 percent of GDP. The distribution of the latter total among individual localities is to be decided by a state-level coordination council. Limits are also envisaged for the total public debt in accordance with the Six-Pack directives (see Section 4 below), with their distribution among government levels to be guided by their respective shares in the current stock of debt. ${ }^{10}$ The Pact also includes a rule limiting the growth of expenditures to that of potential national GDP. Various escape clauses and a debt-brake-type correction mechanism are envisaged in this latest Pact. Monitoring is entrusted to the federal Court of Auditors, and an intergovernmental Conciliation Body is given enforcement powers (including fines) in case of breach of the rules.

The initial results of the 2012 Pact have been encouraging, with subnational deficits declining to below the targets. However, little progress has been made to date on broader intergovernmental fiscal reforms (including increasing sub-national own revenue responsibilities and eliminating expenditure overlaps) that would help harden the sub-national budget constraint and ensure continued compliance with the EU objectives in the future.

The internal stability pact framework in Belgium has involved until recently an annual determination of budgetary targets for the federal and the regional governments, based on the recommendations of the multipartisan High Finance Council (HFC). The latter typically has recommended a distribution of fiscal adjustment efforts between the two levels of government in line with their respective expenditure shares. Ex post, however, the $\mathrm{CG}$ has ended up contributing more.

The national legislation enacting the Fiscal Compact, only approved in late 2013, links more explicitly the fiscal targets to the EU requirements, but still envisages that their distribution between the levels of government will be determined annually through cooperation agreements based on the HFC's recommendations. The latter are supposed to refer henceforth to 
structural budget targets, estimated on the basis of the evolving EC methodology on the subject. The legislation refers to EU rules for the correction of deviations from the targets.

Italy has had a series of Domestic Stability Pacts (DSPs) since 1999, complemented by pacts setting targets for health spending (which is largely a regional responsibility). ${ }^{11}$ Until 2009, the DSPs' balance or expenditure targets were largely determined by the CG. A 2009 framework law to implement the 2001 Constitutional Amendment on intergovernmental fiscal relations - which envisaged a strengthened role for existing fora for intergovernmental dialogue, including on fiscal targets - has remained largely unimplemented. In fact, the Euro crisis and related fiscal consolidation efforts have led to rationalization of levels of government (see Ambrosanio, Balduzzi and Bordignon, Chapter 9 in this volume), with the consolidation of some municipalities, a proposed reduction of the role of the regional tier of government, and a planned elimination of the provincial tier.

The DSPs' targets have been changed frequently, undermining the SNGs' ability to plan. Their increased focus on curbing sub-national spending has contributed to a compression of public investments in infrastructure. Monitoring has been carried out on an ex post basis by the General Accounting Office (Ragioneria Generale) of the Ministry of Economy and Finance, and by the Supreme Audit Court, with significant lags. Further progress is needed in improving the quality and timeliness of sub-national fiscal statistics. The enforcement of the Pacts has been progressively tightened, including through automatic increases in some own taxes for non-complying SNGs.

A recent Constitutional Amendment to implement the Fiscal Compact mandates sub-national contributions to the EU objectives for the structural budget balance and the public debt. ${ }^{12}$ However, the translation of these principles into a detailed legal framework is still in process.

In Spain, fiscal targets for the different levels of government have been set on a multi-annual basis by two successive Budgetary Stability Acts (2001 and 2008). Annual targets ex ante consistent with the requirements of the Acts have been set by the CG, reflecting negotiations with the regional governments in the Council on Fiscal and Financial Policies, which includes the respective Ministers of Finance. ${ }^{13}$ Compliance with the Acts was weakened by significant resort of the regional governments to PPPs and accounting stratagems, and was practically abandoned during the global financial crisis.

Since 2012, negotiations on sub-national targets are carried out within the framework of a new Organic Law on Budgetary Stability, which mandates convergence of the public debt of central, regional and 
local levels of government to 44 percent, 13 percent, and 3 percent of GDP, respectively; limits structural deficits of the general government to no more than 0.4 percent of GDP, and expenditure growth for all governments to that of potential output; and strengthens enforcement mechanisms.

\section{CHALLENGES AHEAD}

\subsection{The EU Fiscal Framework after Recent Reforms}

Recent reforms in the EU fiscal framework (Six-Pack, Fiscal Compact, and Two-Pack, summarized briefly in the Appendix), which are aimed at remedying some of the excessive rigidities of the SGP while strengthening its enforcement, have further complicated the framework and its practical implementation, including with respect to the EA's SNGs. In particular, the reformed framework involves a plethora of targets for, and related constraints on, general government aggregates (Table 1.2).

These multiple targets and constraints may not always be fully consistent. For example, actual deficits below 3 percent of GDP may not ensure a convergence of the public debt to the 60 percent ceiling in a number of countries within the area, if their real GDP growth remains sluggish over the foreseeable future. In contrast, sustained observance of the Medium Term Objective (MTO) could imply a decline of the debt to well under 60 percent of GDP over the longer term in most of the EA members. In addition to potential inconsistencies among themselves, the EU-mandated targets and limits may not always be fully consistent with the national fiscal responsibility legislations, most of which are of a constitutional level and therefore hard to change.

A further concern with the EU framework is that it can unduly constrain the room for public investments, since the MTO target implies that the bulk of the investments should be financed through public savings, irrespective of a country's levels of debt and debt-servicing capacity. This requirement can adversely affect the EU members' longer-term growth potential, as well as inter-generational equity.

Finally, the use of the SBB as a hard numerical target (as opposed to one of a range of indicators of the fiscal policy stance) creates substantial operational challenges. A number of papers have highlighted the difficulties of estimating SBBs in real time - given the substantial revisions that measures of potential output typically undergo over the span of two to three years ${ }^{14}$ - as well as the uncertainties affecting the estimation of the elasticities of revenues to the cycle. Moreover, the identification and 
Table 1.2 Multiplicity of fiscal constraints under the reformed SGP

\begin{tabular}{|c|c|}
\hline Target & Constraint on \\
\hline \multicolumn{2}{|l|}{ Under SGP's preventive arm } \\
\hline Medium-term objective (MTO) & Structural budget balance (SBB) \\
\hline Adjustment path to MTO (at least & Change in SBB \\
\hline $\begin{array}{l}0.5 \text { percent of GDP reduction in } \\
\text { SBB a year) }\end{array}$ & \\
\hline Expenditure rule & Rate of growth of expenditures \\
\hline \multicolumn{2}{|l|}{ Under SGP's corrective arm } \\
\hline 3 percent of GDP deficit limit & Actual budget balance (ABB) \\
\hline 60 percent of GDP debt limit & Gross public debt \\
\hline $\begin{array}{l}1 / 20 \text { th minimum reduction of } \\
\text { excess of debt over } 60 \text { percent limit }\end{array}$ & Change in gross public debt \\
\hline $\begin{array}{l}\text { Country-specific annual budget } \\
\text { deficit limit for countries under } \\
\text { EDP }\end{array}$ & ABB \\
\hline $\begin{array}{l}\text { Annual fiscal effort for countries under } \\
\text { EDP }\end{array}$ & Change in SFB \\
\hline
\end{tabular}

Source: Author's compilation.

quantification of one-off factors to be purged from the SBB measure is also challenging, and can open scope for manipulations of the data.

The risk of manipulations can be reduced by subjecting estimates of the SBB to the scrutiny of independent fiscal 'watchdogs' (the EC and/or national independent fiscal councils, which are in the process of being set up throughout the EU), but the technical challenge of obtaining robust estimates of the SBB is still far from being resolved. ${ }^{15}$ Moreover, the super-imposition of different national and supra-national layers of fiscal monitoring and assessment can give rise to differences and even conflicts, requiring better coordination arrangements than those currently in place in the EU.

\subsection{Implications of the Reformed Framework for the EA's Sub-National Finances}

The fact that the EU-mandated targets and limits for the general government are now backed up by stricter enforcement mechanisms (see the Appendix) makes it more compelling than before for the EA's CGs to put in place effective arrangements to ensure an adequate contribution of their SNGs to the achievement of the targets. This objective poses a number of 
significant challenges in both the design and the implementation of these arrangements.

The main design challenges are:

- To define appropriate criteria and mechanisms for both the vertical and horizontal apportionments of the EU-mandated general government budget targets and debt ceilings;

- To minimize risks of sub-national pro-cyclicality;

- To preserve adequate room for public investments (increasingly a sub-national responsibility); and

- To identify and carry out any structural reforms in the system of intergovernmental fiscal relations needed to promote an effective compliance by SNGs with their respective budget and debt targets.

The main implementation challenges are:

- To ensure a robust legal basis for sub-national fiscal rules/targets;

- To estimate sub-national SBBs;

- To put in place more timely and reliable monitoring arrangements; and

- To strengthen the effectiveness of enforcement and correction mechanisms.

While some of these issues have already been addressed by most EA countries in the national legislations implementing the Fiscal Compact, others remain unresolved so far. The following sub-sections present some reflections on the pending agenda in this area.

\subsubsection{Design issues}

A first question to be addressed refers to the institutional arrangements to be used by the CG in seeking to ensure consistency of sub-national fiscal policies and developments with the EU targets. Specifically, are standing rules preferable to coordination mechanisms of the type of the Internal Stability Pacts?

Rules have the significant advantage of reducing the scope for periodic bargaining, thereby hardening the sub-national budget constraint. They also provide a more stable framework for sub-national planning and budgeting than frequently renegotiated targets and limits. Coordination arrangements, on the other hand, provide more flexibility to adjust subnational fiscal targets to changing economic and fiscal circumstances, including changes in the estimates of the national output gap. They are 
also likely to increase sub-national ownership for the targets, thereby promoting improved compliance.

The appropriate balance of these considerations is likely to vary across the EA countries, reflecting a number of factors, including:

- The legal power of the CG to legislate standing rules for its SNGs;

- The degree of its political leverage on SNGs (standing rules may help relatively weaker governments 'hold the line' against pressures by SNGs to minimize their share of any needed fiscal adjustment); and

- The degree of vulnerability of the country to unforeseeable exogenous shocks (including regionally asymmetric ones) that require adjustments in fiscal policies (coordination arrangements may allow faster and more flexible responses to such shocks than standing rules).

National legislations enacted so far tend to present a mixture of arrangements, with most privileging rules regarding the (vertical) apportionment of the targets among the different levels of government, and negotiations regarding the (horizontal) apportionment within each sub-national level of government.

The appropriate criteria to guide the vertical apportionment of EU targets and limits are difficult to define on a generalized basis. In principle, the criteria should take into account the following main factors:

- Initial conditions (e.g., the respective aggregate budget disequilibria and levels of debt of the different levels of government);

- The degree of dependence of the state and local levels of government on transfers from higher levels (the case for balanced budgets is more compelling for SNGs that are very dependent on CG transfers); and

- The relative rigidities and socio/political sensitivities of the expenditures assigned to the different levels of government.

In practice, however, the relative contributions of different government levels are also likely to be significantly influenced by political economy factors, especially the balance of respective political powers.

The appropriate criteria for the horizontal distribution of targets and limits are also difficult to generalize. Distribution formulas should take into account initial conditions (i.e., the relative balance and debt levels of individual SNGs, requiring more adjustment from SNGs with larger initial imbalances), as well as relative debt-servicing capacities. SNGs with higher own-revenue efforts, and thus greater debt-servicing capacity, should be allowed greater borrowing room than those with lower ones. On the other 
hand, differences in revenue-raising capacities, as well as in expenditure needs or costs, should be dealt with through equalization transfers, not through differentiation in rules/targets. Of course, a reliable measurement of revenue capacities and efforts as well as expenditure needs is a challenging task (although a number of EU countries, including Spain and the Scandinavian countries, have made considerable progress in this regard), and both the criteria for target apportionment and the design of equalization transfers may have to be based on second-best proxies of those variables. It is however important to avoid using actual levels, as this changes the incentive structures underlying the formulations and may lead to increasing deficits.

Given the substantial (and often growing) weight of sub-national investments in total public investments in most EA countries, preserving some room for such investments within the constraints imposed by the EU framework constitutes a significant challenge for the area countries. It is clear that an unfettered resort to borrowing by SNGs to finance their investments is inconsistent with the EU framework. However, CGs can create limited room for debt-financed sub-national investments by increasing their own savings. If compatible with the statutory sub-national autonomy in the country, the CG could define an aggregate limit (a kind of pool) for permits to borrow to finance sub-national investments, and set up a bidding mechanism for SNGs to access such a pool. ${ }^{16}$ The project bids should be supported by well-articulated business cases, including costbenefit analyses based on standardized methodologies.

An additional important challenge for governments of the EA is to reduce the risk of sub-national fiscal pro-cyclicality. In principle, specifying sub-national budget targets in structural terms could minimize such risks. This approach would be consistent with the increasing focus on the SBB in the EU fiscal framework. However, the already substantial difficulties in estimating SBBs in a timely and robust way at the CG level are magnified at the sub-national level, in particular by:

- The fact that regional and local economies are subject to idiosyncratic, and typically asymmetric, shocks that make estimates of subnational SBBs based on national output gaps quite problematic; and

- The longer lags in availability of sub-national GDP data.

Therefore, other approaches to mitigating sub-national pro-cyclicality risks may be preferable in practice, namely:

- The use of structural or moving averages of actual CG revenues as a basis for revenue sharing; 
- The use of trend revenues to calculate proxies of structural balances; and

- A requirement for SNGs to save revenue windfalls into 'rainy day' funds, with clearly specified rules for withdrawals.

\subsubsection{Implementation issues}

It is essential to ensure a robust legal basis for any framework to promote sub-national fiscal discipline. Countries' approaches to this task have to reflect their specific institutional context. In federal-type countries, the statutory treatment of sub-national autonomy may require higher-level legislation as the basis for sub-national rules. This has been largely achieved in the EA with the legislation implementing the Fiscal Compact. However, the issues mentioned above that are not covered by this legislation are likely to have to be resolved mainly through negotiated arrangements (preferably multi-year ones). This may require the creation of new intergovernmental coordination fora, or the strengthening of existing ones. ${ }^{17}$

As regards monitoring arrangements, a first issue to be addressed is who should monitor sub-national compliance with the rules or agreed targets? Possible candidates are: the CG's Ministry of Finance; a Secretariat of the intergovernmental coordination forum; the country's Supreme Audit Court; or the national Fiscal Council. There are advantages and disadvantages to each option. Assigning the responsibility to the national Ministry of Finance would maximize the chances of prompt responses to sub-national fiscal slippages. On the other hand, SNGs are likely to favor the other options that they are likely to view as more 'neutral'; and they may carry sufficient political weight to have their preferences prevail.

Improving the timeliness and reliability of sub-national fiscal data is crucial for strengthening the effectiveness of any sub-national monitoring arrangement. Appropriate steps in this direction would include:

- Enacting legislation requiring all SNGs to follow standardized accounting and reporting requirements, consistent with those used for fiscal surveillance by the EU;

- Requiring improved reporting of fiscal risks from PPPs, guarantees, and other explicit contingent liabilities;

- Increasing frequency and reducing lags in sub-national fiscal reporting (in particular for states/regions and large localities); and

- Introducing and consistently applying penalties for failures to report as required.

As concerns enforcement mechanisms, an effective design of sanctions needs to take into account a number of country-specific factors: 
- The degree of statutory and de facto autonomy of the SNGs;

- Their degree of financial dependence on transfers from CG; and the compulsory or discretionary nature of such transfers (cuts in discretionary CG transfers can constitute effective sanctions for non-compliant SNGs);

- The possible role of intergovernmental coordination fora in enforcement;

- The legal scope for administrative intervention in case of serious violations that raise the risk of a financial crisis; and

- The legal scope for holding sub-national government officials accountable for serious failures in compliance.

It is also important to introduce or strengthen correction mechanisms for sub-national deviations from the targets. Such correction arrangements could be modeled (in a simplified manner) on the example of the Swiss 'debt brake' system ${ }^{18}$ (although see Milbradt, Chapter 3 in this volume; and Spahn, Chapter 4 in this volume for some limitations).

\section{CONCLUSIONS}

The crises that have buffeted the EA in recent years have taken a substantial toll on the public finances of most countries in the area at both the national and the sub-national levels. With the average general government deficit still slightly above 3 percent of GDP, the average structural deficit still above 1 percent of GDP, and the public debt above 95 percent of GDP, it is clear that further sustained fiscal adjustment will be needed in the years ahead, although its pace should vary appropriately both across the countries in the area and over time.

The recent reforms in the EU fiscal framework have aimed at strengthening the likelihood of such adjustment, not only by introducing some elements of flexibility (increased focus on the SBB, and differentiated paths of adjustment depending on initial conditions), but also by strengthening enforcement. In the process, however, the framework has been significantly complicated, creating further challenges, especially as regards its application to the sub-national levels of government.

This chapter has provided an initial exploratory discussion of these challenges, as well as in the light of EA members' experiences with the application of the previous versions of the framework. A lesson that emerges clearly from those experiences is that there is no one-size-fits-all prescription for ensuring an appropriate contribution of SNGs to fiscal convergence under the EU framework. Some countries have privileged 
more or less permanent sub-national fiscal rules (on balances, debt or spending); others more negotiated arrangements, reflecting different institutional settings and political power balances. There is no firm evidence that one approach has been consistently more effective than the others. It is also clear that weaknesses in monitoring and enforcement mechanisms have significantly undermined the effectiveness of both rules and negotiated arrangements, especially in the run-up to the global crisis when market discipline was conspicuously absent (including at the sub-national level) in the EA.

Looking forward, while the national legislations implementing the Fiscal Compact have addressed some of the complex design and implementation issues that the revised EU framework poses for inter-governmental fiscal relations in the EA, more reflection is clearly needed on a number of these issues. This chapter has put forward some initial thoughts on such issues, while recognizing the preponderant role that political economy factors are likely to play in this area.

In particular the chapter has discussed some of the criteria that should guide the vertical and horizontal apportionment of the EU-mandated deficit and debt targets. It has also advanced suggestions on safeguarding some room for sub-national investments within the (probably too strict) constraints posed by the EU framework.

Reducing pro-cyclicality in sub-national policies remains a challenging task, in the EA as elsewhere. Given the state of technology in estimating output gaps and the still relatively long lags in the availability of subnational data, the, in principle, best approach of specifying sub-national budget targets in structural terms does not appear very practical at the present time. The chapter has suggested some second-best, but probably more feasible, approaches in this area.

Finally, improving monitoring, enforcement and correction mechanisms for sub-national rules or negotiated targets is crucial to improve their effectiveness. The chapter has indicated a number of steps that could and should be taken as soon as possible toward these objectives.

\section{NOTES}

1. A recent paper by the EC, 2014, estimates the overall structural consolidation effort in the EA (excluding Cyprus, Greece and Latvia) in 2013 to have amounted to about 0.7 percent of GDP, albeit with significant variance across the area members.

2. The EA members' Stability and Convergence programs for 2014 target a slower pace of structural fiscal adjustment, equivalent on average to about 0.3 percent of GDP. The average debt-to-GDP ratio in the area is projected to peak in 2014, but to remain well above the 60 percent target for many years to come. 
3. For analyses of the effects of the global financial crisis on SNG finances in the OECD, see Ter-Minassian and Fedelino (2010); Blochliger et al. (2010); Foremny and von Hagen, 2012; and Wolman (2014).

4. The central government's share of overall general government expenditures ranged from 60 percent in Finland to 94 percent in Greece in 2012. The corresponding share in revenues ranged from 57 percent in Spain to nearly 97 percent in Greece. Accordingly, SNGs' dependence on transfers from the CG varies significantly across the EA, albeit remaining well above 50 percent on average.

5. Among the large EU (and more broadly OECD) countries, Italy was the only one that did not introduce discretionary stimulus measures, and indeed did not fully accommodate the automatic stabilizers, a fact that resulted in some fiscal pro-cyclicality (Ambrosanio et al., Chapter 9 in this volume). This reflected concerns with fiscal sustainability, given the already high level of the country's public debt at the outset of the crisis.

6. This stylized overview is intended to capture the key features of individual countries' arrangements, rather than to provide a detailed description of each of the latter (a task beyond the scope of this chapter). More details can be found in EC (2012).

7. Most EA countries, however, have not put in place legislation envisaging formal bankruptcy procedures for distressed localities, such as, e.g., Chapter 9 of the US Bankruptcy Code (see Canuto and Liu, 2013, for details).

8. For a discussion of empirical evidence on the importance of such factors in determining the softness of the sub-national budget constraint, see Ter-Minassian (2015).

9. Since 2002, Spain has shifted to a more rules-based framework.

10. Specifically, 88 percent for the CG; 8 percent for the states; 2 percent for Vienna; and 2 percent for the other municipalities.

11. See Piperno (2013) for a comprehensive analysis of the Italian DSPs.

12. Specifically, regions are required to ensure not only equilibrium in their own budgets, but also in the aggregate budget of the local governments within their territory (albeit not of each individual locality).

13. See Tournemire (2014).

14. See, e.g., Kempkes (2012).

15. In its annual Reports on the Public Finance in the EU, the EC discusses ongoing work and advances in this area.

16. A similar mechanism (fondo concursable) is used at the CG level in Chile to determine which new investments should be included in the budget each year.

17. Tournemire (2014) provides a comprehensive review of current intergovernmental coordination forums in the EU.

18. For a description of this system see Danninger (2002).

\section{REFERENCES}

Blochliger, H. (2013), 'Fiscal Consolidation across Government Levels - Part 1. How Much, What Policies?', OECD Economics Department Working Papers, No. 1070, Paris.

Blochliger, H., Charbit, C., Pinero Campos, J.M. and Vammalle, C. (2010), 'SubCentral Governments and the Economic Crisis', OECD Economics Department Working Papers No. 752, Paris.

Canuto, O. and Liu, L. (2013), 'Until Debt Do Us Part: Subnational Debt, Insolvency, and Markets', World Bank, Washington, DC.

Danninger, S. (2002), 'A New Rule: The Swiss Debt Brake', IMF Working Paper $02 / 18$. 
Escolano, J., Eyraud, L., Moreno Badia, M., Sarnes, J. and Tuladhar, A. (2012), 'Fiscal Performance, Institutional Design and Decentralization in EU Countries', IMF Working Paper 12/45.

European Commission (EC) (2012), 'Report on Public Finances in the EU', Brussels.

European Commission (EC) (2013), 'Report on Public Finances in the EU', Brussels.

Foremny, D. and von Hagen, J. (2012), 'Fiscal Federalism in Times of Crisis', Centre for Economic Policy Research, Discussion Paper No. 9154, London.

Kempkes, G. (2012), 'Cyclical Adjustment in Fiscal Rules: Some Evidence on RealTime Bias for EU-15 Countries', Discussion Paper, Deutsche Bundesbank No. $15 / 2012$.

OECD, Fiscal Decentralisation Database, http://www.oecd.org/tax/federalism/ oecdfiscaldecentralisationdatabase.

Piperno, S. (2013), La finanza decentrata in Italia, Bologna: Il Mulino.

Schaechter, A., Kinda, T., Budina, N. and Weber, A. (2012), 'Fiscal Rules in Response to the Crisis - Toward the "Next-Generation" Rules. A New Dataset', IMF Working Paper 12/187.

Ter-Minassian, T. and Fedelino, A. (2010), 'Impact of the Global Crisis on Sub-National Governments' Finances', Bank of Italy's Proceedings of Public Finance Workshop.

Ter-Minassian, T. (2015), 'Promoting Responsible and Sustainable Fiscal Decentralization', in Ahmad, E. and Brosio, G. (eds), Handbook of Multilevel Finance, Cheltenham, UK and Northampton, MA, USA: Edward Elgar, pp. 437-58.

Tournemire, G. (2014), 'Coordination Arrangements across Government SubSectors in EU Member States', European Economy Economic Papers 517, Brussels.

Truger, A. and Will, H. (2012), "The German "Debt Brake" - A Shining Example for European Fiscal Policy?', Institute for International Political Economy Working Paper No. 15, Berlin.

Wolman, H. (2014), 'National Fiscal Policy and Local Government during the Economic Crisis', German Marshall Fund, Urban Papers Series. 


\section{APPENDIX THE NEW EU FISCAL GOVERNANCE FRAMEWORK $^{1}$}

The economic and fiscal governance of the EA and of the rest of the EU has been significantly strengthened in the wake of the Euro crisis, which exposed fundamental weaknesses in its previous design, and especially in its enforcement. The main building blocks of the reformed framework are: a set of five Regulations and one Directive, effective from December 2011 (the so-called Six-Pack); the Treaty on Stability, Coordination and Governance (the so-called Fiscal Compact) signed in 2012 and now ratified by all signatories; and two additional Regulations approved in 2013 (the so-called Two-Pack). They are briefly summarized in what follows.

\section{The Six-Pack}

The Six-Pack applies to the $27 \mathrm{EU}$ members, with some specific rules for EA members, especially regarding financial sanctions. It covers not only fiscal surveillance, but also macroeconomic surveillance under the new Macroeconomic Imbalance Procedure.

In the fiscal area, the Six-Pack strengthens the Stability and Growth Pact (SGP). It reinforces both the preventive and the corrective arm of the Pact, i.e. the Excessive Deficit Procedure (EDP), which applies to Member States that have breached the 3 percent of GDP deficit debt limit. The Six-Pack ensures stricter application of the SGP's fiscal rules by defining quantitatively what a 'significant deviation' from the medium-term objective (MTO) for the structural fiscal balance, or the adjustment path toward it, means in the context of the preventive arm.

Moreover, the six-pack operationalizes the SGP's debt rule, so that an EDP may also be launched if the debt-to-GDP ratio of a member country exceeds 60 percent and is not declining toward the limit at a satisfactory pace (defined as at least by $1 / 20$ th of the excess per year). It also includes an expenditure benchmark, specifying that the growth of expenditures should not exceed that of potential GDP, but does not envisage sanctions for non-compliance with the rule.

Financial sanctions are imposed on non-complying EA members in a gradual way, from the preventive arm to the latest stages of the EDP, and may eventually reach $0.5 \%$ of GDP. The Six-Pack introduces reversequalified majority voting (RQMV) for most sanctions, thereby increasing the likelihood of their implementation.

To ensure an effective implementation of these fiscal rules, the Six-Pack sets out a number of broad recommendations to make medium-term budget frameworks more binding, prepare budgets in a more top-down 
sequence, report more frequently, timely, and comprehensively on fiscal developments and risks, and give a bigger role to independent fiscal councils for the preparation of budget assumptions as well as the assessment of compliance with the rules.

\section{The Fiscal Compact}

The Treaty on Stability, Coordination and Governance (TSCG), the fiscal part of which is referred to as the Fiscal Compact, requires contracting parties to approve higher, preferably constitutional-level national legislation to ensure convergence (at paces to be agreed with the EC) toward the revised SGP targets, namely structural deficits no higher than 0.5 percent of GDP, ${ }^{2}$ nominal deficits no higher than 3 percent of GDP, and public debt no higher than 60 percent of GDP.

The national legislations have to include automatic correction mechanisms for deviation from the MTO, or the adjustment path toward it, with escape clauses for exceptional circumstances. Compliance with the rules is to be monitored by independent institutions. The European Court of Justice $(\mathrm{CoJ})$ may impose financial sanctions ( 0.1 percent of GDP) if a country does not properly implement the new budget rules in national law and fails to comply with a $\mathrm{CoJ}$ ruling requiring it to do so.

\section{The Two-Pack}

The so-called Two-Pack legislation, which entered into force at the end of May 2013, contains different initiatives aimed at strengthening economic coordination and surveillance in the EA. It subjects the area's members experiencing severe financial instability, or receiving financial assistance on a precautionary basis, to a new form of enhanced surveillance. It seeks to better articulate any financial assistance provided outside the framework of the EU (e.g. under the European Stability Mechanism, ESM) with the Treaty. For this purpose, it sets out specific procedures for ensuring the consistency of ESM-supported adjustment programs with the EU's reformed macroeconomic and fiscal framework. The legislation also creates a system of post-program surveillance for countries that have received financial assistance, until at least 75 percent of the latter have been repaid.

The Two-Pack also includes provisions aiming to increase accountability and transparency. In particular, this regards the involvement of the national and the European parliaments, as well as the involvement of other relevant stakeholders, in the new procedures set out in the legislation. 


\section{Notes}

1. This Appendix is largely based on Schaechter et al. (2012); and on EC documentation available at: http://ec.europa.eu/economy_finance/articles/governance/2012-0314_six_pack_en.htm.

2. 1.0 percent of GDP for Member States with a debt ratio significantly below 60 percent of GDP. 